\title{
Low-Cost Green Car Purchase Intention: Measuring the Role of Brand Image on Perceived Price and Quality
}

\author{
Submitted 20/03/19, 1st revision 27/04/19, 2nd revision 18/05/19, accepted 20/07/19
}

\author{
Usep Suhud ${ }^{1}$, Greg Willson²
}

\begin{abstract}
:
Purpose: The study tests a rhombus model. A rhombus model refers to a rhombus-shaped research model consisting of three predictor variables including brand image, perceived price, and perceived quality that is used to predict purchase intention. This study aims to predict a person's purchase intention relating to Low-Cost Green Cars (LCGC). In Indonesia market, this type of passenger vehicle is targeted towards lower income consumers and those who are concerned with the environment.

Design/Methodology/Approach: Data was collected using a questionnaire in a shopping centre in Jakarta close to a year-round car exhibition. In total, 200 participants completed the questionnaire. Data were analysed using exploratory factor analysis and structural equation modeling.

Findings: The study found that in the case of Toyota Agya, brand image has a significant impact on perceived price and perceived quality. Also, perceived price has a significant impact on purchase intention. There are slightly different results in the case of Daihatsu Ayla.

Practical Implications: Results can be used by managerial administration adjusting its strategy to attract more costumers.

Originality/Value: It is an original research with prospective buyers for a known product, the brand name of the cars were known to participants in the research.
\end{abstract}

Keywords: Low-cost green car, structural equation model, brand image, perceived price, perceived quality, rhombus model, group analysis

JEL codes: $O 13, Q 20, Q 28$.

Article type: Research study.

\footnotetext{
${ }^{1}$ Faculty of Economics, Universitas Negeri Jakarta, Indonesia, usuhud@unj.ac.id

${ }^{2}$ Faculty of Business and Law, Edith Cowan University, Australia
} 


\section{Introduction}

For most Indonesian consumers, cars are still relatively expensive. Only those with substantial income who afford to buy this kind of product. Considering this fact, automotive manufacturers developed cheaper cars to target lower income consumers. Since September 2013, the manufacturers, including Toyota, Daihatsu, Honda, and Datsun, produced and launched Low-Cost Green Cars (LCGC) (Teresia, 2013). Since then, Agya from Toyota and Ayla from Daihatsu lead the market of this car category in Indonesia They have taken market share from their competitors including Brio Satya (Honda), Go+ Panca and Go Panca (Datsun), and Wagon R (Suzuki) (Wicaksono \& Muhardi, 2016).

According to Sanjaya and Indriani (2014), customers who purchased an LCGC are motivated by lower prices, environmentally friendly, enhanced self-image, adhering to a social norm, social pressure, and interest in a new technology. Indeed, in general, customers who purchase a green car are motivated by the same reasons (Ozaki \& Sevastyanova, 2011) as well as to support an environmental policy (Coad, De Haan \& Woersdorfer, 2009). There are only a few prior studies that have focussed on exploring the factors to influence LCGC purchase intention. Putri (2017) chose environment awareness, product innovation, and perceived quality as predictor variables. Firmansyah and Untarini (2016) used product knowledge and perceived quality. Furthermore, Indrawati and Suparna (2015) selected product knowledge and perceived price. Additionally, Hudrasyah (2016) applied nationalism as predictor variables. In this study, the authors include brand image as an independent variable, perceived price and perceived value as mediating variables, and purchase intention as a dependent variable. These four variables shape a rhombus model. This model is considered as an innovation carried out by this current study. Besides, there is limited study exploring the impact of brand image on perceived price.

Having a product with a green brand in a product line benefits the manufacturers particularly with creating a favourable brand attitude (Hartmann, Apaolaza-Ibáñez \& Sainz, 2005). Further, this green attitude will lead consumers to green purchase intention (Hartmann \& Apaolaza-Ibáñez, 2012). Green purchase intention or purchase intention in general can be influenced by various variables, directly or indirectly, including brand image, perceived quality, and perceived price. Prior research documented that brand image can positively influence perceived price, brand equity, store image perception, perceived quality, customer satisfaction, trust, and loyalty (Chiang \& Jang, 2007; Malik, Ghafoor \& Iqbal, 2012b; Sallam, 2016; $\mathrm{Wu}$, Liao, Chen \& Hsu, 2011). Furthermore, perceived price can positively influence purchase intention, repurchase intention, and loyalty (Anuwichanont, 2011; Malik, Yaqoob \& Aslam, 2012a). In addition, perceived quality can positively influence brand preference, satisfaction, purchase intention, and loyalty (Afsar, 2014; Malik et al., 2012a). Therefore, the authors address questions whether the 
intention of participants of this current study to purchase an LCGC will be affected by brand image, perceived price, and perceived value.

The study selects brand image as a dependent variable, perceived price or perceived price and perceived quality as mediating variables, and purchase intention as the predicted variable. Therefore, the study aims to measure the impact of brand image, perceived price, and perceived quality on intention to purchase a LCGC using a rhombus model.

\section{Literature Review}

\subsection{Brand Image, Perceived Price and Perceived Quality}

Brand image is defined by Keller (1993) as "perceptions about a brand as reflected by the brand associations held in consumer memory". In this study, brand image is linked to perceived price and perceived quality. There is a limited research examining the impact of brand image on perceived price. Lien, Wen, Huang and $\mathrm{Wu}$ (2015) studied the intention of travellers to book hotel online. They tested the impact of brand image on perceived price, value, and trust as well as purchase intention. They documented that brand image positively influenced those four variables.

Furthermore, previous studies have purported that brand image is an important key to predict perceived quality. Hou and Wonglorsaichon (2011) studied internet users in China. One of the hypotheses tested by these scholars was the influence of brand image on perceived quality of anti-virus software. They reported that brand image impacted perceived quality. In a study presented by Cakmak (2016) brand image was used to predict perceived risk, perceived quality, and brand trust. This scholar reported that brand image affected perceived risk and perceived quality significantly. Additionally, Aberdeen, Syamsun and Najib (2016) tested brand image on perceived quality to compared two carbonated drink brand names: Coca Cola and Big Cola. The results showed that in both Coca Cola and Big Cola cases, brand image significantly influenced perceived quality.

\subsection{Perceived Price and Purchase Intention}

Price represents an 'input' in the process of consumer's purchase decision and this input will influence a 'process' (such as perception, motivation, and intention) and it leads to an 'output' (such as purchase, repurchase, and loyalty) (Schiffman \& Wisenblit, 2015). In this case, a price will influence a consumer' perceived price.

A car, even though it may be claimed as cheap or affordable by marketers, refers to a large amount of money. To purchase or even to have a purchase intention, people will consider their income and overall financial situation. In many cases, there will be a negative impact of income on purchase intention (Wong \& Mo, 2013). In addition, level of perception on a price can be different between one person and 
another (Zeithaml, 1988). In this study, perceived price or perceived price is linked to brand purchase intention.

Lichtenstein, Ridgway and Netemeyer (1993) established two constructs of price perception including negative role of price and positive role of price. Negative role of price consists of value consciousness, price consciousness, coupon proneness, sale proneness, and price mavenism. Furthermore, positive role of price consists of price-quality schema and prestige sensitivity. In a Taiwanese study, Wang and Chen (2016) explored the impact of perceived price, perceived value, perceived risk, purchase situation, and purchase intention. Six of the seven hypotheses they tested were accepted.

With a setting of an online book store, Setiawan and Achyar (2012) chose perceived trust, perceived price, and perceived value to predict purchase intention on that store. They demonstrated that all these predictor variables had a significant impact on the intention to purchase items in that online book store.

Price perception was also chosen by Munnukka (2008) to question whether this variable had an effect on purchase intention. Another study by Tih and Lee (2013) focussed on store brands conducted. Both Munnukka (2008) and Tih and Lee (2013) showed a significant impact of price perception on purchase intention. Furthermore, consumer behaviour on online hotel booking became a focus of Chiang and Jang (2007). By selecting university students at a university in the USA, these scholars found results consistent with previous studies. Another study conducted in Indonesia by Indrawati and Suparna (2015) explore the role of price perception on LCGC purchase intention. As a result, they showed a significant impact of price perception on purchase intention.

\subsection{Perceived Quality and Purchase Intention}

Perceived quality is defined as "the consumer's judgment about a product's overall excellence or superiority" (Tsiotsou, 2006). Conducting a research in China, Chi, Yeh and Yang (2009) tested the impact of perceived product on loyalty and purchase intention and concluded that there was a significant impact from one to another. Other studies linked perceived quality to purchase intention and brand profitability (Aberdeen et al., 2016; Yaseen, Tahira, Gulzar \& Anwar, 2011) and maintained the same finding. In addition, Firmansyah and Untarini (2016) and Putri (2017) chose perceived quality to predict LCGC purchase intention and documented that there was a significant impact of perceived quality on this environmentally vehicle purchase intention.

This study is addressed to examine a rhombus-shaped model as illustrated below. This model is the innovation offered by the authors. This model has four paths: brand image to perceived price, brand image to perceived quality, perceived price to purchase intention, and perceive product quality to purchase intention. However, as 
there are two brands name to compare, in total there are eight hypotheses to be examined.

H1 ab: Brand image significantly influences perceived price of Toyota Agya/Daihatsu Ayla.

$H 2_{a b}$ : Brand image significantly influences perceived quality of Toyota Agya/Daihatsu Ayla.

$H 3_{a b}$ : Perceived price significantly influences purchase intention of Toyota Agya/Daihatsu Ayla.

H4 ${ }_{a b}$ : Perceived product quality significantly influences purchase intention of Toyota Agya/Daihatsu Ayla.

Figure 1. The proposed research model

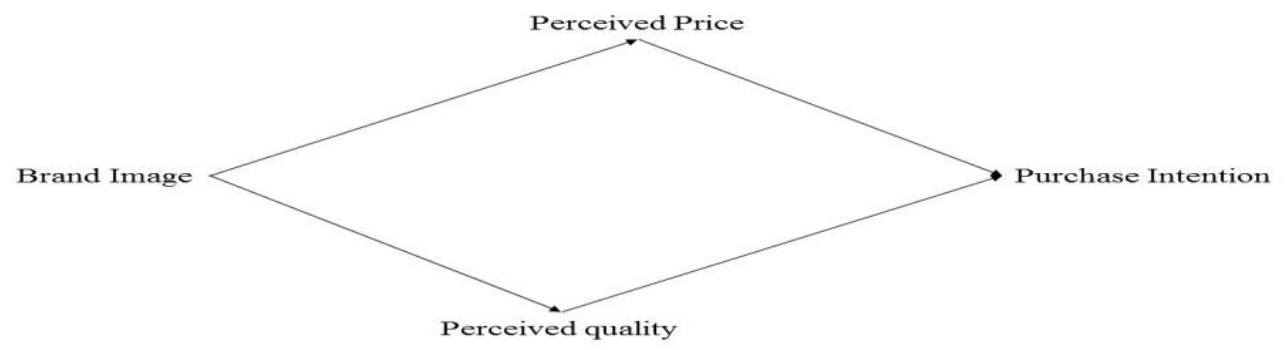

\section{Research Methodology}

Data was collected within an international trade centre (ITC) in Central Jakarta. Based on the authors' observation, the majority of people visiting this destination were local Indonesians. The visitors were approached conveniently to participate in the survey. The mall consists of several clusters of shops including fashion, textile, gadgets, and general convenience stores. There was an international hyper mart on the ground floor. In front of this hyper mart, there was an empty space and regularly there was a car exhibition. Around this space, the authors distributed questionnaires within May-June 2015.

To validate the study, the authors took and adapted items that have been tested by prior studies. A five-point scale is applied for all variable, ranging from 1 for strongly disagree to 5 for strongly agree. The questionnaire consisted of three parts relating to screening for eligibility, variables (brand image, price perception, perceived quality, and purchase intention), and personal profile (sex, gender, marital status, education, income, and marital status). For the questions related to variables, participants were asked to fill in two columns of scale. The first column was for measuring Toyota Agya and the second column was used for measuring Daihatsu Ayla. Therefore, in total, 200 participants completed 400 data entries. Originally, some items were in English. As the participants were Indonesians, the items were translated and adapted into Bahasa Indonesia. 
To test the instrument, the authors conducted a pilot study consisting of 50 participants. The data collected was analysed using exploratory factor analysis. The results suggested for revisions. This was made before the survey was completed.

Data collected were analysed in two steps. The first step was exploratory factor analysis using rotation direct oblimin, followed by a reliability test for each factor. The second step was structural equation model to measure the proposed research framework. The last step was structural equation model with criteria: a probability score of $\geq 0.05$ (Schermelleh-Engel, Moosbrugger \& Müller, 2003) and CMIN/DF score of $\leq 2$ (Tabachnick \& Fidell, 2007). In addition, a CFI score of $\geq 0.97$ (Hu \& Bentler, 1995), and a RMSEA score of $\leq 0.05$ (Hu \& Bentler, 1999). As this is a comparative study, a group analysis was applied.

\section{Results}

In total, 200 participants were recruited with 92 males (46\%) and 108 females 54\%). Predominantly, participants were aged between 25-34 years (96), followed by 20-24 years old 84). Almost 57\% (113) of them were single, and more than $40 \%$ (83) were married. When they were asked to indicate their occupation, 119 participants said that they worked at a private company, while 39 participants were a civil servant, 17 participants were self-employed, 14 participants were university students, and 11 participants were others. Most participants specified their monthly income to be less than US \$ 500 (100), while others were between US \$ 500-1000 (81), US \$ 10012000 (17), and more than US \$ 2000 (2). In total, 168 participants domiciled in Jakarta and the rest were Indonesian residents domiciled out of Jakarta. The majority of participants travelled to the mall used a motorbike (90), public transport (75), car (32), and others (3).

Based on EFA outcome, four components were resulted and each variable only produced a component. Price perception retains all items with a Cronbach's alpha score of 0.929 , on the other hand, three variables must drop some items. Specifically, two items of brand image are dropped: Bil ("Toyota Agya/Daihatsu Ayla car has a few choice car types") and Bi2 ("Toyota Agya/Daihatsu Ayla car reminds me of the fuel-efficient cars"). This component obtains a Cronbach's alpha score of 0.953. Two items of purchase intention are also left: Pi4 ("I am willing to recommend Toyota Agya/Daihatsu Ayla to others (friends, family, spouse)") and Pi5 ("I like to compare car Toyota Agya/Daihatsu Ayla with other car brands"). This component has a Cronbach's alpha score of 0.915 .

Perceived quality retains 13 items whereas another three items are dropped: Pq12: ("Design Toyota Agya/Daihatsu Ayla car is the best"), Pq13 ("Toyota Agya/Daihatsu Ayla offers many attractive features"), and Pq14 ("Features offered by Toyota Agya/Daihatsu Ayla meet my expectations of the quality"). This component has a Cronbach's alpha score of 0.933 . 
Table 1. Result of exploratory factor analysis

\begin{tabular}{|c|c|c|c|}
\hline & Indicators & \begin{tabular}{|l|l} 
Factor \\
loadings
\end{tabular} & $\begin{array}{l}\text { Cronbach's } \\
\text { alpha }\end{array}$ \\
\hline 1 & Brand image & & 0.953 \\
\hline bi9 & Toyota/Daihatsu deeply understands the interests of consumers & 0.771 & \\
\hline bi8 & Toyota/Daihatsu very concerns about the interests of consumers & 0.711 & \\
\hline bi6 & Toyota Agya/Daihatsu Ayla car reflects the younger generation & 0.709 & \\
\hline bi2 & Toyota Agya/Daihatsu Ayla car reminds me of the fuel-efficient cars & 0.632 & \\
\hline bi1 & Toyota Agya/Daihatsu Ayla car has a few choice car types & 0.624 & \\
\hline bi10 & $\begin{array}{l}\text { The sales network of Toyota/Daihatsu is very spacious, so products } \\
\text { are easily obtainable }\end{array}$ & 0.576 & \\
\hline bi3 & $\begin{array}{l}\text { Toyota Agya/Daihatsu Ayla car reminds me of the classy and } \\
\text { famous cars }\end{array}$ & 0.572 & \\
\hline bi5 & $\begin{array}{l}\text { Toyota Agya/Daihatsu Ayla car reminds me of the dynamic and } \\
\text { trendy car }\end{array}$ & 0.568 & \\
\hline bi4 & $\begin{array}{l}\text { Toyota Agya/Daihatsu Ayla car reminds me of the environmentally } \\
\text { friendly cars }\end{array}$ & 0.549 & \\
\hline bi13 & Toyota/Daihatsu is a reliable company in producing cars & 0.533 & \\
\hline bi11 & $\begin{array}{l}\text { Toyota Agya/Daihatsu Ayla car is easily searchable and available at } \\
\text { dealers everywhere }\end{array}$ & 0.530 & \\
\hline bi12 & Toyota/Daihatsu has a good reputation in producing cars & 0.517 & \\
\hline bi7 & Toyota Agya /Daihatsu Ayla car suits my personality & 0.509 & \\
\hline 2 & Purchase intention & & 0.915 \\
\hline pi7 & $\begin{array}{l}\text { I keep looking information Relating to Toyota Agya/Daihatsu Ayla } \\
\text { cars }\end{array}$ & 0.870 & \\
\hline pi8 & $\begin{array}{l}\text { I intend to visit Toyota Agya/Daihatsu Ayla exhibition in the near } \\
\text { future }\end{array}$ & 0.821 & \\
\hline pil & I intend to buy a Toyota Agya/Daihatsu Ayla car in the near future & 0.740 & \\
\hline pi6 & $\begin{array}{l}\text { I would buy a car Toyota Agya/Daihatsu Ayla product compared to } \\
\text { other brand cars }\end{array}$ & 0.678 & \\
\hline pi2 & I am sure Toyota Agya/Daihatsu Ayla is suitable to me to buy & 0.648 & \\
\hline pi3 & I always talk about Toyota Agya/Daihatsu Ayla with friends & 0.565 & \\
\hline 3 & Perceived quality & & 0.933 \\
\hline $\mathrm{pq} 4$ & $\begin{array}{l}\text { Toyota Agya/Daihatsu Ayla car was made to be used for long periods } \\
\text { of time }\end{array}$ & 0.735 & \\
\hline pq2 & Cars offered by Toyota/Daihatsu have the greatest performance & 0.707 & \\
\hline pq1 & Quality of Toyota Agya/Daihatsu Ayla is excellent & 0.690 & \\
\hline pq3 & Toyota/Daihatsu provides a reliable guarantee to car owners & 0.678 & \\
\hline pq11 & $\begin{array}{l}\text { Toyota Agya/Daihatsu Ayla stable when used for long distance usage } \\
\text { of the cars }\end{array}$ & 0.662 & \\
\hline pq5 & $\begin{array}{l}\text { Spare parts and accessories offered by Toyota Agya /Daihatsu Ayla is } \\
\text { durable }\end{array}$ & 0.627 & \\
\hline pq9 & Toyota Agya/Daihatsu Ayla has a good performance on the streets & 0.618 & \\
\hline pq7 & Toyota Agya/Daihatsu Ayla has a quality replacement parts & 0.594 & \\
\hline pq10 & Toyota Agya/Daihatsu Ayla has a good engine durability & 0.542 & \\
\hline pq6 & Auto parts Toyota Agya /Daihatsu Ayla car is easily obtained & 0.421 & \\
\hline $\mathrm{pq} 8$ & Service centre Toyota Agya/Daihatsu Ayla is easily searchable & 0.401 & \\
\hline 4 & Perceived price & & 0.929 \\
\hline pr2 & $\begin{array}{l}\text { The price offered by Toyota Agya /Daihatsu Ayla is acceptable, } \\
\text { compared to other brands of cars }\end{array}$ & 0.742 & \\
\hline pr3 & Price of Toyota Agya/Daihatsu Ayla car is very reasonable & 0.699 & \\
\hline pr1 & $\begin{array}{l}\text { The prices of Toyota Agya/Daihatsu Ayla car have a higher } \\
\text { economic value than other cars }\end{array}$ & 0.698 & \\
\hline
\end{tabular}


\begin{tabular}{|l|l|l|l}
\hline pr8 & Price of Toyota Agya/Daihatsu Ayla car is offered in accordance the 0.673
\end{tabular} purchasing power of Indonesian society

pr5 Prices offered by Toyota Agya/Daihatsu Ayla line with my 0.658 expectations

pr6 Prices of Toyota Agya/Daihatsu Ayla are in accordance with the 0.650 performance of the car has to offer

\begin{tabular}{l|l|l} 
pr4 Price of Toyota Agya/Daihatsu Ayla car is not expensive & 0.642
\end{tabular}

$\begin{array}{lll}\text { pr7 Prices of cars are offered in accordance with the quality of the car } & 0.595\end{array}$

\subsection{Hypoteses Testing}

The proposed research model to predict Ayla purchase intention achieved a fitted model with a probability score of 0.233 , CMIN/DF of 1.071 , CFI of 0.977 , and RMSEA of 0.019 .

Figure 2. Structural model of Toyota Agya purchase intention

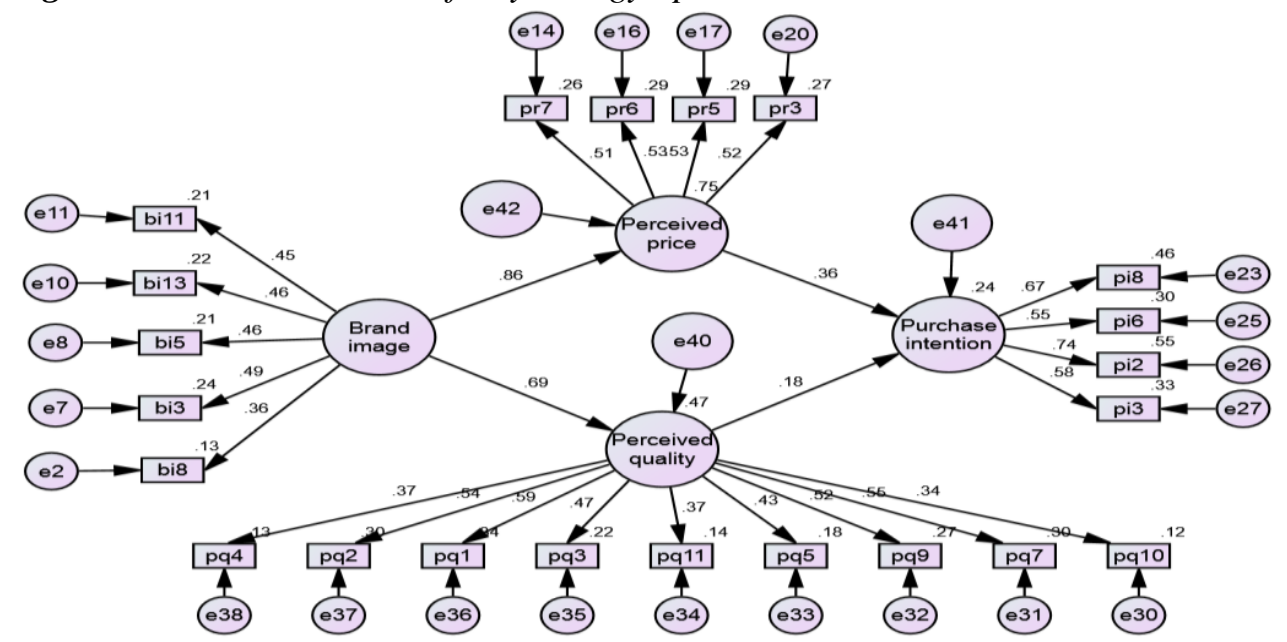

For Ayla construction, a fitted model is achieved with probability, CMIN/DF, CFI, and RMSEA scores of $0.275,1.054,0.980$, and 0.016 respectively.

\section{Discussion and Conclusion}

Table 2 below presents the results of hypotheses testing both for Toyota Agya and Daihatsu Ayla. The first hypothesis predicted the impact of brand image on perceived price. In both models, this path had a C.R. score of 4.361 and 2.079 respectively. As the scores were significant, therefore, $\mathrm{H}_{1}$ was accepted. This is evidence that the more positive the brand image of an LCGC, the more positive perceived price will be. This finding supports a prior study conducted by Lien $e t$ al. (2015). 
The second hypothesis was to predict the impact of brand image on perceived quality. This study demonstrated a C.R. score of 3.862 for Toyota Agya and 2.176 for Daihatsu Ayla. These scores were considered significant and therefore, $\mathrm{H}_{2}$ was accepted. It means that the more positive a brand image of an LCGC, the more positive the product quality is perceived. This finding supports prior studies (Aberdeen et al., 2016; Cakmak, 2016; Hou \& Wonglorsaichon, 2011).

Perceived quality would predict purchase intention was the third hypothesis. In the case of Toyota Agya, the path had a C.R. score of 1.323 which was insignificant. This is surprising. In fact, Toyota Agya was the highest selling LCGC since the car type was launched. Toyota and Daihatsu competed against each other not only within the LCGC category, but also at other categories. Even though the public realised that for some of Toyota's vehicles, the products were manufactured by Daihatsu, yet Toyota's products maintain a good perception in the public's mind in terms of quality. In this case, the authors assume that there was a confusion amongst participants of this study of the ownership of both brand names, whether Ayla or Agya belongs to Toyota. On the other hand, in the case of Daihatsu Agya, it has a C.R. score of 3.087wchich shows a significant response. Therefore, in the case of Toyota Ayla, $\mathrm{H}_{3}$ is rejected. Contrary, in the case of Daihatsu Agya, $\mathrm{H}_{3}$ is accepted. The finding of the Daihatsu Agya case is significant with existing studies (Aberdeen et al., 2016; Chi et al., 2009; Yaseen et al., 2011).

Furthermore, the fourth hypothesis predicts the impact of perceived price on purchase intention. In the case of Toyota Agya, the path has a C.R. score of 2.407 which is significant. This finding supports prior studies (Chiang \& Jang, 2007; Munnukka, 2008; Setiawan \& Achyar, 2012; Tih \& Lee, 2013; Wang \& Chen, 2016). Oppositely, in the case of Daihatsu Agya, the path owns a C.R. score of 0.778. This is far away from the score of the same path in the Toyota Ayla case. In the market, the prices of Toyota's products are higher compared to the prices of Daihatsu's products including for LCGCs. Indeed, Toyota still leads the automotive market for some categories. Participants apparently believed that the higher prices of Toyota would result in value for money.

Table 2. Summary of hypotheses testing for Toyota Agya and Daihatsu Ayla

\begin{tabular}{|l|lll|l|l|}
\hline & Paths & & & Toyota Agya & Daihatsu Ayla \\
\cline { 4 - 6 } & & & C.R. & C.R. \\
\hline $\mathrm{H}_{1}$ & Brand image & $\rightarrow$ & Perceived price & 4.361 & 2.079 \\
$\mathrm{H}_{2}$ & Brand image & $\rightarrow$ & Perceived quality & 3.862 & 2.176 \\
$\mathrm{H}_{3}$ & Perceived quality & $\rightarrow$ & $\begin{array}{l}\text { Purchase } \\
\text { intention }\end{array}$ & 1.323 & 3.087 \\
$\mathrm{H}_{4}$ & Perceived price & $\rightarrow$ & $\begin{array}{l}\text { Purchase } \\
\text { intention }\end{array}$ & 2.407 & 0.778 \\
& & & & \\
\hline
\end{tabular}


To conclude, this study aimed to examine the impact of brand image on perceived price and perceived quality and their impact on the intention to purchase LCGC. Two brand names of LCGC were selected, the Toyota Ayla and Daihatsu Agya as two of the highest selling LCGC within Indonesia. In the case of Toyota Ayla, three hypotheses are significant including the impact of brand image on perceived price and perceived quality, and perceived price on purchase intention. In the case of Daihatsu Agya, brand image significantly influences perceived price and perceived quality, and perceived quality significantly purchase intention. The rhombus model as tested does not work properly to predict purchase intention of LCGC, particularly to compare two cases with data analysis methods applied in this study.

\section{Limitations and Future Research Directions}

In the study participants were selected conveniently without any certain criteria. The authors consider this as the limitation of this study.

The selection of the international trade centre as the place for exhibition could be an issue for car sellers. Looking at the participants' profile, especially for the monthly income and daily transport mode choice, the visitors were not the main target of LCGC. Besides, both cases have imperfection perceived by participants. In the case of Toyota Agya, product quality was perceived insignificant whereas in the case of Daihatsu Ayla, price was perceived insignificant. The authors assume that there was miss-matched of brand names perception. Agya was perceived as a Daihatsu's product and Ayla was perceived as a Toyota's product. Practically, Toyota as the umbrella brand name of Agya was the one that had a 'bigger' name than Daihatsu. It advices that sellers and marketers should emphasise marketing programs that could make consumers differentiate the brand names appropriately.

Future studies should apply purposive sampling by collecting data only from those who own one of these vehicles. If this is the case, participants will have experience purchasing and using a care would have a better understanding on price and quality. Besides, it is also important to consider selecting participants from a higher income level. Once again, price does always matters to influence perceptions. Future studies may also consider using the rhombus model for measuring purchase and/or repurchase intention for any products with the variables discussed above.

\section{References:}

Aberdeen, N.I., Syamsun, M. \& Najib, M. 2016. The effect of brand awareness and image on consumer perceived quality and purchase itension - A sudy case of carbonated drink brand at Bogor City. International Journal of Scientific and Research Publications, $6(8)$.

Afsar, B. 2014. Effect of perceived price, brand image, perceived quality and trust on consumer's buying preferences. Journal of Economics and Business Research, 20(1), 7-20. 
Anuwichanont, J. 2011. The impact of price perception on customer loyalty in the airline context. Journal of Business \& Economics Research (JBER), 9(9), 37-50.

Cakmak, I. 2016. The role of brand awareness on brand image, perceived quality and effect on risk in create brand trust. Global Journal on Humanities and Social Sciences, (4), 177-186.

Chi, H.K., Yeh, H.R. \& Yang, Y.T. 2009. The impact of brand awareness on consumer purchase intention: The mediating effect of perceived quality and brand loyalty. Journal of International Management Studies, 4(1), 135-144.

Chiang, C.F. \& Jang, S.S. 2007. The effects of perceived price and brand image on value and purchase intention: Leisure travelers' attitudes toward online hotel booking. Journal of Hospitality \& Leisure Marketing, 15(3), 49-69.

Coad, A., De Haan, P. \& Woersdorfer, J.S. 2009. Consumer support for environmental policies: An application to purchases of green cars. Ecological Economics, 68(7), 2078-2086.

Firmansyah, A.R. \& Untarini, N. 2016. The impact of product knowledge and perceived quality on the intention to purchase Datsun Go Panca (in Bahasa Indonesia). Jurnal Ilmu Manajemen (JIM), 4(1), 1-7.

Hartmann, P. \& Apaolaza-Ibáñez, V. 2012. Consumer attitude and purchase intention toward green energy brands: The roles of psychological benefits and environmental concern. Journal of Business Research, 65(9), 1254-1263.

Hartmann, P., Apaolaza-Ibáñez, V. \& Sainz, F.J.F. 2005. Green branding effects on attitude: Functional versus emotional positioning strategies. Marketing Intelligence \& Planning, 23(1), 9-29.

Hou, C. \& Wonglorsaichon, P. 2011. The relationship among brand awareness, brand image, perceived quality, brand trust, brand loyalty and brand equity of customer in china's antivirus software industry. International Journal of Business and Economics, 8(1).

Hu, L.T. \& Bentler, P.M. 1999. Cutoff criteria for fit indexes in covariance structure analysis: Conventional criteria versus new alternatives. Structural Equation Modeling: A Multidisciplinary Journal, 6(1), 1-55.

Hudrasyah, H. 2016. Studies on customer attractiveness and customer purchase intention to "LCDC" vehicles made in Indonesia. Progress and Communication in Sciences, 2(2), 39-46.

Indrawati, K.D. \& Suparna, G. 2015. Price perception role in moderating the effect of product knowledge towards intention to purchase environment-friendly products: A case of Toyota Agya (in Bahasa Indonesia). E-Jurnal Manajemen Universitas Udayana, 4(7), 1816-1830.

Keller, K.L. 1993. Conceptualizing, measuring, and managing customer-based brand equity. Journal of marketing, 57(1), 1-22.

Lichtenstein, D.R., Ridgway, N.M. \& Netemeyer, R.G. 1993. Price perceptions and consumer shopping behavior: A field study. Journal of Marketing Research, 234.

Lien, C.H., Wen, M.J., Huang, L.C. \& Wu, K.L. 2015. Online hotel booking: The effects of brand image, price, trust and value on purchase intentions. Asia Pacific Management Review, 20(4), 210-218.

Malik, F., Yaqoob, S. \& Aslam, A.S. 2012a. The impact of price perception, service quality, and brand image on customer loyalty (study of hospitality industry in Pakistan). Interdisciplinary Journal of Contemporary Research in Business, 4(5).

Malik, M.E., Ghafoor, M.M. \& Iqbal, H.K. 2012b. Impact of brand image, service quality and price on customer satisfaction in Pakistan telecommunication sector. International Journal of Business and Social Science, 3(23), 123-129. 
Munnukka, J.2008). Customers' purchase intentions as a reflection of price perception. Journal of Product \& Brand Management, 17(3), 188-196.

Ozaki, R. \& Sevastyanova, K. 2011. Going hybrid: An analysis of consumer purchase motivations. Energy Policy, 39(5), 2217-2227.

Putri, E.O.M. 2017. The effect of environmental awareness, product innovation, and quality perception of the intention to purchase Suzuki Karimun Wagon R AGS: A study of the Suzuki Karimun Wagon R AGS exhibition visitors at the Royal Plaza and Giant Margorejo Surabaya (in Bahasa Indonesia). Jurnal Ilmu Manajemen (JIM), 5(1).

Sallam, M.A. 2016. The Impact of Brand Image and Corporate Branding on Consumer's Choice: The Role of Brand Equity. International Journal of Marketing Studies, 8(1).

Sanjaya, K.K. \& Indriani, T.D. 2014. Customers motivation to purchase Low Cost Green Car in Indonesia. Journal of Business and Management, 3(6), 646-655.

Schermelleh-Engel, K., Moosbrugger, H. \& Müller, H. 2003. Evaluating the fit of structural equation models: Tests of significance and descriptive goodness-of-fit measures. Methods of Psychological Research Online, 8(2), 23-74.

Schiffman, L.G. \& Wisenblit, J. 2015. Consumer behaviour. New Jersey: Pearson Education.

Setiawan, R. \& Achyar, A. 2012. Effects of Perceived Trust and Perceived Price on Customers' Intention to Buy in Online Store in Indonesia. ASEAN Marketing Journal, 26-36.

Tabachnick, B.G. \& Fidell, L.S. 2007. Using multivariate statistics (5 ed.). Boston Pearson/Allyn \& Bacon.

Teresia, A. 2013. Honda to launch LCGC this week. https://en.tempo.co/read/news/2013/09/09/056511668/Honda-to-Launch-LCGCThis-Week

Tih, S. \& Lee, K.H. 2013. Perceptions and Predictors of Consumers? Purchase Intentions for Store Brands: Evidence from Malaysia. Asian Journal of Business and Accounting, $6(2)$.

Tsiotsou, R. 2006. The role of perceived product quality and overall satisfaction on purchase intentions. International journal of consumer studies, 30(2), 207-217.

Wang, Y.H. \& Chen, L.Y. 2016. An Empirical Study of the Effect of Perceived Price on Purchase Intention Evidence from Low-Cost Carriers. International Journal of Business and Social Science, 7(4), 97-107.

Wicaksono, K. \& Muhardi, H. 2016. Daihatsu moves Toyota for LCGC highest sellers. Daihatsu Ayla be the highest sales during February 2016 (in Bahasa Indonesia).

Wong, W.M. \& Mo, H.F. 2013. Automobile purchase intention of consumers in a multiracial society: A hierarchical regression analysis model. The Journal of Applied Business and Economics, 14(1), 110.

Wu, C.C., Liao, S.H., Chen, Y.J. \& Hsu, W.L. 2011. Service quality, brand image and price fairness impact on the customer satisfaction and loyalty. Paper presented at the Industrial Engineering and Engineering Management (IEEM), 2011 IEEE International Conference.

Yaseen, N., Tahira, M., Gulzar, A. \& Anwar, A. 2011. Impact of brand awareness, perceived quality and customer loyalty on brand profitability and purchase intention: A resellers' view. Interdisciplinary Journal of Contemporary Research in Business, 3(8), 833-839.

Zeithaml, V.A. 1988. Consumer perceptions of price, quality, and value: A means-end model and synthesis of evidence. The Journal of Marketing, 52(3), 2-22. 